\title{
ANALISIS KEPUASAN KONSUMEN MADU LOKAL DI KOTA PONTIANAK
}

\section{ANALYSIS OF LOCAL HONEY COSTUMER SATISFACTION IN PONTIANAK}

\author{
Natalia Lelo Mali, Eva Dolorosa*, Novira Kusrini \\ Prodi Agribisnis, Fakultas Pertanian Universitas Tanjungpura \\ Jl. Prof. Dr. H. Hadari Nawawi No 1 Pontianak \\ *E-mail: eva.dolorosa@faperta.untan.ac.id \\ (Diterima 26-04-2021; Disetujui 03-06-2021)
}

\begin{abstract}
ABSTRAK
Madu adalah zat alami yang dihasilkan lebah dari bahan baku netral bunga. Madu merupakan salah satu komoditi hasil hutan bukan kayu yang memberikan banyak manfaat. Madu. Tujuan penelitian ini adalah untuk menganalisis kepuasan konsumen madu Syaiful di kota Pontianak. Pada penelitian ini, peneliti mengambil 100 orang responden sebagai sampel, dan melalui 5 dimensi yaitu dimensi kualitas produk, dimensi kualitas pelayanan, dimensi harga, dimensi emosional, dimensi kemudahan dan biaya akan diketahui atribut-atribut apa saja yang perlu dipertahankan kinerjanya, ditingkatkan atau dikurangi, serta menentukan prioritas utama, pertahankan prestasi, prioritas rendah dan prioritas berlebihan kedalam diagram kartesius. Pengambilan sampel secara accidental sampling konsumen yang kebetulan bertemu dengan peneliti untuk di analisis menggunakan Importance Performance Analysis (IPA) dan Customer Satisfaction Index (CSI). Hasil IPA menunjukkan bahwa atribut dari kepuasan konsumen yang dijadikan prioritas utama dalam peningkatan kinerja pelaksanaannya adalah warna madu, aroma madu, karyawan berpenampilan rapi, harga terjangkau, harga sesuai kualitas produk, dan bangga mengkonsumsi madu lokal. Hasil CSI menunjukkan tingkat kepuasan konsumen madu Syaiful masuk kedalam kategori PUAS dengan nilai $71,20 \%$.
\end{abstract}

Kata kunci : Madu, Kepuasan Konsumen, CSI, IPA

\begin{abstract}
Honey is a natural substance that bees produce from flower-neutral raw materials. Honey is one of the commodities of non-timber forest products that provide many benefits. The purpose of this research was to analyze the satisfaction of the honey consumers to Syaiful in Pontianak city. In this study there were 100 key respondents to answer questionnaires. Through five dimensions namely product quality dimensions, service quality dimensions, price dimensions, emotional dimensions, and ease dimensions will be known attributes - what attributes need to be maintained, performance, improved or reduced and determine the top priority, maintain achievements, low priority and excessive priority into cartesian diagrams. Respondents with accidental sampling who happened to meet with researchers to be analyzed using Importance Performance Analysis (IPA) and Customer Satisfaction Index (CSI). IPA results showed that the dimensions of consumer satisfaction that became the main priority in improving the performance of its implementation are honey color, honey aroma, neat-looking employees, affordable prices, prices according to product quality, proud to consume local honey. CSI results showed that the contingency satisfaction level in Syaiful honey shop fell into the category of satisfied with avalue of $71.20 \%$.
\end{abstract}

Keywords : Honey, customer satisfaction, CSI, IPA 


\section{PENDAHULUAN}

Madu merupakan salah satu komoditi hasil hutan bukan kayu yang mempunyai banyak manfaat. Sejak jaman dahulu madu sudah dikenal dan digunakan sebagai obat herbal untuk mengobati berbagai jenis penyakit ataupun sebagai bahan minuman untuk kebugaran tubuh, daya tahan tubuh, penyakit dan sebagai bahan kosmetik. Seiring timbulnya kesadaran akan manfaat dari madu terhadap kesehatan tubuh membuat permintaan madu di kalangan masyarakat meningkat, sehingga muncul berbagai jenis merek madu di kota Pontianak, seperti yang kita ketahui Kalimantan Barat merupakan salah satu daerah penghasil madu. Diantara banyaknya merek madu lokal yang ada di kota Pontianak, terdapat salah satu toko madu yaitu madu Syaiful yang berdiri sejak tahun 2012 mempunyai beberapa jenis madu lokal yang dipanen langsung dari hutan. Beberapa jenis merek madu Syaiful yang dipanen langsung dari hutan Kalimantan Barat antara lain madu Syaiful kelutut, madu Syaiful mangrove dan madu Syaiful standar lokal. Madu Syaiful memilih kelebihan baik dari produk, kualitas, warna, aroma, variasi, dan manfaat sehingga permintaan jauh lebih banyak dibandingkan merek madu lokal lainnya. Perbedaan dari penelitian tentang madu sebelumnya dengan penelitian yang dilakukan peneliti terhadap merek madu Syaiful adalah peneliti memilih madu lokal khusus wilayah Kalimantan Barat, sedangkan pada penelitian-penelitian terdahulu atau penelitian sebelumnya memicu pada penelitian madu secara umum di Indonesia.

Penelitian ini bertujuan untuk mengetahui tingkat kepuasan konsumen madu Syaiful di Kota Pontianak. Menurut (Irawan, 2009), kepuasan konsumen adalah hasil akumulasi dari konsumen dalam menggunakan produk dan jasa. Konsumen puas kalau setelah membeli produk dan menggunakan produk tersebut, ternyata kualitas produknya baik. Menurut (Irawan, 2009), ada lima faktor yang mempengaruhi kepuasan konsumen yaitu kualitas produk, kualitas pelayanan, harga, emosional, dan kemudahan. (, Kotler ; , Philip ; , Amstrong, 2012), kepuasan konsumen merupakan perbedaan antara kinerja yang dirasakan dengan harapan. Apabila kinerja di bawah harapan konsumen, maka konsumen akan merasa kecewa dan akan beralih ke produk lainnya. Sebaliknya, jika kinerja sesuai dengan harapan konsumen maka konsumen akan 
merasa sangat puas. Faktor yang menentukan kepuasan konsumen ada lima dimensi, yaitu kualitas produk, kualitas pelayanan, harga, emosional, dan kemudahan. Pada hakikatnya lima dimensi tersebut berpengaruh terhadap keputusan pembelian konsumen dengan pendekatan yang mempertimbangkan tingkat kepentingan dan tingkat kinerja dari atribut-atribut yang diukur.

\section{METODE PENELITIAN}

Lokasi penelitian dilakukan di toko Syaiful J1. R.E. Mardinata Sungai Jawi Dalam, dengan populasi dalam penelitian ini adalah seluruh masyarakat kota Pontianak yang membeli dan mengkonsumsi madu Syaiful lebih dari 3 bulan. Penentuan lokasi penelitian di toko Syaiful karena konsumen madu Syaiful beragam dan tingkat permintaan madu Syaiful jauh lebih tinggi dibandingkan produk madu lokal merek lainnya.

Metode yang digunakan pada penelitian ini adalah metode deskriptif dengan studi kasus pada toko Syaiful. Lokasi penelitian dilakukan secara purposive sampling, pengambilan sampel dilakukan secara non- probality sampling dengan teknik accidental sampling dengan mengambil 100 responden.
Dalam penelitian ini data primer bersumber dari penyebaran kuesioner secara langsung kepada konsumen madu Syaiful yang berada di kota Pontianak yang memenuhi kriteria yang dibutuhkan dalam penelitian, dimana hasil dari data tersebut dikumpulkan dan diperoleh sendiri oleh peneliti dan data sekunder dapat diperoleh dari berbagai sumber seperti Badan Pusat Statistik ( BPS ), buku, laporan, jurnal dan lain-lain. Pengambilan data digunakan menggunakan wawancara, kuesioner, dan observasi.

Untuk mengetahui preferensi kepuasan konsumen oleh konsumen madu Syaiful di Kota Pontianak, dan dapat menggunakan skala likert dengan menjabarkan beberapa item pertanyaan yang disusun dalam kuesioner, dan dan setiap pertanyaan diberi skor senilai dengan pilihan tesponden. Teknik analisis data menggunakan Customer Satisfaction Index (CSI), yaitu untuk menentukan tingkat kepusan konsumen secara menyeluruh dengan pendekatan yang mempertimbangkan tingkat kepentingan dan tingkat kinerja dari atribut-atribut yang diukur. $\quad \mathrm{CSI}=\frac{\sum_{\mathrm{i}=1}^{\mathrm{p}} \mathrm{WS}_{\mathrm{i}}}{H S} \times 100 \%$, sedangkan Important Performance Analysis (IPA) digunakan untuk mengukur atribut dari tingkat kinerja 
dengan harapan yang diinginkan konsumen.

\section{HASIL DAN PEMBAHASAN}

Pada penelitian ini penulis memperoleh data melalui penyebaran kuesioner sebanyak 100 kuesioner dengan 20 pertanyaan. Pada penelitian ini karakteristik yang diamati meliputi usia, jenis kelamin, pendidikan terakhir, pekerjaan, wilayah, dan pendapatan.

Tabel 1. Karakteristik konsumen

\begin{tabular}{|c|c|c|}
\hline Karakteristik & $\begin{array}{c}\text { Jumlah } \\
\text { Orang }\end{array}$ & Presentase \\
\hline \multicolumn{3}{|l|}{ Jenis Kelamin } \\
\hline Laki - Laki & 67 & $67 \%$ \\
\hline Perempuan & 33 & $33 \%$ \\
\hline \multicolumn{3}{|l|}{ Usia } \\
\hline $17-25$ Tahun & 23 & $33 \%$ \\
\hline 26 - 35 Tahun & 34 & $39 \%$ \\
\hline $36-45$ Tahun & 30 & $20 \%$ \\
\hline $46-55$ Tahun & 13 & $8 \%$ \\
\hline \multicolumn{3}{|l|}{$\begin{array}{l}\text { Wilayah Tempat } \\
\text { Tinggal }\end{array}$} \\
\hline Pontianak Selatan & 17 & $17 \%$ \\
\hline Pontianak Tenggara & 17 & $17 \%$ \\
\hline Pontianak Kota & 15 & $15 \%$ \\
\hline Pontianak Timur & 16 & $16 \%$ \\
\hline Pontianak Utara & 9 & $9 \%$ \\
\hline Pontianak Barat & 26 & $26 \%$ \\
\hline \multicolumn{3}{|l|}{ Pendidikan } \\
\hline SD & 1 & $1 \%$ \\
\hline SMP & 10 & $10 \%$ \\
\hline SMA & 42 & $42 \%$ \\
\hline DIPLOMA & 17 & $17 \%$ \\
\hline SARJANA & 30 & $30 \%$ \\
\hline \multicolumn{3}{|l|}{ Pekerjaan } \\
\hline Pelajar / Mahasiswa & 9 & $9 \%$ \\
\hline Wiraswasta & 45 & $45 \%$ \\
\hline Pegawai Swasta & 11 & $11 \%$ \\
\hline Pegawai Negeri Sipil & 20 & $20 \%$ \\
\hline Lainnya & 15 & $15 \%$ \\
\hline \multicolumn{3}{|l|}{ Pendapatan (Rp) } \\
\hline$<1.500 .000$ & 13 & $13 \%$ \\
\hline $1.500 .000-$ & 42 & $42 \%$ \\
\hline
\end{tabular}

\begin{tabular}{lcc}
\hline 2.500 .000 & & \\
$2.600 .000-$ & 42 & $42 \%$ \\
5.000 .000 & 3 & $3 \%$ \\
$>5.000 .000$ & 3 & \\
\hline
\end{tabular}

Sumber : data primer 2020

Berdasarkan kelompok usia, responden yang mengkonsumsi madu Syaiful didominasi oleh kelompok usia 26-35 tahun sebesar 39\%. Hal ini disebabkan pada usia seperti ini memiliki aktivitas yang cukup padat, jadi konsumen memilih mengkonsumsi madu sebagai pengganti olahraga agar tetap bugar dan kekebalan tubuh selalu terjaga. Hasil penelitian (Putriwindani, 2011) menyatakan rentang usia 26-35 tahun mengkonsumsi madu untuk menunjang kesehatan di tengah kesibukan mereka, dan memiliki ketertarikan dalam mengkonsumsi madu karena madu sangat baik untuk kesehatan tubuh. Karakteristik umum responden yang terlibat pada penelitian ini yakni kaum laki-laki sebesar 67\%. Hal ini disebabkan laki-laki memiliki aktitivas yang lebih beras dibandingan perempuan. Penelitian (Nugraha, 2013) menyatakan yang dominan mengkonsumsi madu adalah laki-laki. Hal ini dikarenakan laki-laki lebih dominan menjaga stamina tubuh, kurangnya waktu untuk berolaraga membuat mereka memilih untuk konsumsi madu agar sistem kekebalan tubuh tetap terjaga. 
Pada kategori tingkat pendidikan, rata-rata responden madu Syaiful lulusan SMA. semakin tinggi tingkat pendidikan, maka kesadaran pola hidup sehat jauh lebih diperhatikan. Konsumen dengan tingkat pendidikan yang lebih baik akan responsif terhadap informasi dan pengetahuan yang didapatkan dalam melakukan pembelian. Pada kategori pekerjaan rata-rata responden memiliki pekerjaan sebagai wiraswasta karena kesibukan wiraswasta tidak punya jadwal yang pasti membuat sebagian wiraswasta menjadikan madu sebagai pengganti olahraga atau sebagai obat untuk mengobati penyakit tertentu, dan untuk meningkat daya tahan tubuh dan kebugeran tubuh.

Pada kategori pendapatan rata-rata responden memilih pendapatan $\mathrm{Rp}$ 1.500 .000 - Rp 2.500.000 karena berhubungan erat dengan pendidikan terakhir SMA, dan pekerjaan sebagai wiraswasta. Biasanya pendapatan wiraswasta tidak tetap, namum biasanya yang didapat tidak kurang $\mathrm{Rp}$ 1.500.00. Pada kategori wilayah tempat, rata-rata responden berasal dari Pontianak Barat. Konsumen yang memiliki wilayah tempat tinggal di Pontianak Barat dalam melakukan pembelian di toko Syaiful karena lokasinya mudah dijangkau.

\section{Uji Validitas dan Realibilitas}

Perhitungan validitas menunjukan bahwa keseluruhan pertanyaaan yang diajukan kepada responden dalam penelitian ini dinyatakan valid jika kriteria pengambilan keputusan $r_{\text {hitung }}>$ $r_{\text {tabel }}$ dimana $r_{\text {tabel }}$ adalah 0,196 pada tingkat signifikan sebesar 5\% selanjutnya 20 pertanyaan diuji melalui perhitungan realibilitas. Berdasarkan kriteria pengambilan keputusan dimana nilai cronbach's alpha untuk tingkat kepentingan sebesar $0,760>0,06$ dan untuk tingkat kinerja $0,847>0,06$ sehingga dari 20 pertanyaan dinyatakan reliabel.

\section{Tingkat Kepuasan Konsumen}

Pengukuran tingkat kepuasan konsumen sangat penting dilakukan untuk mengatahui seberapa besar kinerja yang terpenuhi oleh toko madu Syaiful. Perhitungan CSI menggunakan skor ratarata tingkat kepentingan dan tingkat kinerja dari masing-masing atribut (Tabel 2). 
Tabel 2. Nilai tingkat kepentingan dan tingkat kinerja

\begin{tabular}{llcccc}
\hline \multirow{2}{*}{ No Atribut } & & \multicolumn{2}{c}{ tingkat kepentingan } & \multicolumn{2}{c}{ tingkat kinerja } \\
& & MIS & Wf $(\%)$ & MSS & WS(\%) \\
\hline 1 & Cita rasa madu & 3,87 & 5,1 & 3,62 & 18,46 \\
2 & manfaat madu & 4,16 & 5,48 & 4,01 & 21,98 \\
3 & warna madu & 3,64 & 4,8 & 3,44 & 16,5 \\
4 & aroma madu & 3,51 & 4,62 & 3,44 & 15,91 \\
5 & variasi madu & 3,7 & 4,87 & 3,35 & 16,33 \\
6 & kemasan madu & 3,97 & 5,23 & 3,68 & 19,25 \\
7 & kehigenisan madu & 3,83 & 5,05 & 3,74 & 18,87 \\
8 & kebersihan ruangan & 3,98 & 5,24 & 3,6 & 18,87 \\
9 & kesopanan karyawan & 4,06 & 5,35 & 3,74 & 20 \\
10 & karyawan berpenampilan rapi & 3,53 & 4,65 & 3,35 & 15,58 \\
11 & pengetahuan karyawan tentang madu & 3,82 & 5,03 & 3,38 & 17,01 \\
12 & kecepatan melayani & 3,91 & 5,15 & 3,54 & 18,23 \\
13 & kecepatan merespon keluhan konsumen & 3,67 & 4,83 & 3,47 & 16,78 \\
14 & keterjangkauan harga & 3,59 & 4,73 & 3,47 & 16,41 \\
15 & harga sesuai kualitas madu & 3,57 & 4,7 & 3,35 & 15,75 \\
16 & potongan harga & 4,04 & 5,32 & 3,68 & 19,59 \\
17 & bangga mengkonsumsi produk local & 3,75 & 4,94 & 3,34 & 16,5 \\
18 & bangga membeli produk lokal yang bermerek & 3,81 & 5,02 & 3,59 & 18,02 \\
19 & lokasi mudah dijangkau & 3,82 & 5,03 & 3,67 & 18,47 \\
20 & produk tersedia ditempat & 3,68 & 4,85 & 3,6 & 17,45 \\
\hline & Total & 75,91 & 100 & 71,06 & 355,94 \\
\hline & & & & \\
\hline Sul & CSI & $(355.94 / 5$ & $=71,2$ & & \\
\end{tabular}

Sumber : Analisis Data Primer 2020

Berdasarkan dari hasil perhitungan diperoleh CSI sebesar $71,20 \%$ dimana apabila dimasukkan ke kriteria kepuasan konsumen memiliki kriteria "puas". Penelitian ini sejalan dengan (Putriwindani, 2011) yang juga melakukan penelitian kepuasan konsumen madu yang menunjukkan nilai CSI sebesar $71,47 \%$ dimana nilai tersebut termasuk dalam kategori puas. Meskipun demikian, madu Syaiful masih perlu meningkatkan kinerjanya karena masih terdapat $28,8 \%$ konsumen yang kepuasaannya belum dapat dipenuhi oleh madu Syaiful karena kinerjanya saat ini. Oleh karena itu, madu Syaiful perlu memperbaiki dan meningkatkan kinerja produk dan pelayanan agar dapat memaksimalkan nilai kepuasan konsumen. Selanjutnya menunjukan besar nilai GAP dan tingkat kesesuaian suatu atribut agar dalam memudahkan dalam memahami kondisi pada suatu atribut. Hal ini dapat dilihat pada Tabel 3. 
Tabel 3. Nilai GAP dan Tingkat Kesesuaian

\begin{tabular}{|c|c|c|c|c|c|}
\hline No & Atribut & (MIS) & (MSS) & GAP & $\begin{array}{c}\text { tingkat } \\
\text { seskesesuain }(\%)\end{array}$ \\
\hline 1 & Cita rasa madu & 3,87 & 3,62 & $-0,25$ & 93,54 \\
\hline 2 & manfaat madu & 4,16 & 4,01 & $-0,15$ & 96,39 \\
\hline 3 & warna madu & 3,64 & 3,44 & $-0,2$ & 94,51 \\
\hline 4 & aroma madu & 3,51 & 3,44 & $-0,07$ & 98,01 \\
\hline 5 & variasi madu & 3,7 & 3,35 & $-0,35$ & 90,54 \\
\hline 6 & kemasan madu & 3,97 & 3,68 & $-0,29$ & 92,70 \\
\hline 7 & kehigenisan madu & 3,83 & 3,74 & $-0,09$ & 97,65 \\
\hline 8 & kebersihan ruangan & 3,98 & 3,6 & $-0,38$ & 90,45 \\
\hline 9 & kesopanan karyawan & 4,06 & 3,74 & $-0,32$ & 92,12 \\
\hline 10 & karyawan berpenampilan rapi & 3,53 & 3,35 & $-0,18$ & 94,90 \\
\hline 11 & pengetahuan karyawan tentang madu & 3,82 & 3,38 & $-0,44$ & 88,48 \\
\hline 12 & kecepatan melayani & 3,91 & 3,54 & $-0,37$ & 90,54 \\
\hline 13 & kecepatan merespon keluhan konsumen & 3,67 & 3,47 & $-0,2$ & 94,55 \\
\hline 14 & keterjangkauan harga & 3,59 & 3,47 & $-0,12$ & 96,66 \\
\hline 15 & harga sesuai kualitas madu & 3,57 & 3,35 & $-0,22$ & 93,84 \\
\hline 16 & potongan harga & 4,04 & 3,68 & $-0,36$ & 91,09 \\
\hline 17 & bangga mengkonsumsi produk local & 3,75 & 3,34 & $-0,41$ & 89,07 \\
\hline 18 & bangga membeli produk lokal yang bermerek & 3,81 & 3,59 & $-0,22$ & 94,23 \\
\hline 19 & lokasi mudah dijangkau & 3,82 & 3,67 & $-0,15$ & 96,07 \\
\hline \multirow[t]{4}{*}{20} & produk tersedia ditempat & 3,68 & 3,6 & $-0,08$ & 97,83 \\
\hline & Total & 75,91 & 71,06 & & \\
\hline & rata - rata & 3,80 & 3,55 & & \\
\hline & Custumer Satisfaction Index (CSI) & & & & 0,712 \\
\hline
\end{tabular}

Sumber : Analisis Data Primer, 2020

Berdasarkan analisis pada Tabel 3, atribut yang memiliki tingkat kesesuaian terendah yaitu atribut pengetahuan karyawan tentang madu dengan nilai tingkat kesesuai sebesar $88,48 \%$ dan atribut bangga mengkonsumsi produk lokal dengan nilai tingkat kesesuai sebesar $89,07 \%$, sehingga perlu adannya perbaikan terhadap atribut pengetahuan karyawan tentang madu dan atribut bangga mengkonsumsi produk lokal. Pada atribut pengetahuan karyawan tentang madu memiliki tingkat kesesuaian sebesar $\quad 88,48 \%$ artinya konsumen belum merasakan kepuasan terhadap atribut ini karena pengetahuan karyawan tentang produk, ukuran, aroma, dan manfaat masih kurang. Oleh karena itu, pihak madu Syaiful perlu melakukan peningkatan lagi terhadap kedua atribut tersebut dengan cara memberi bimbingan atau pelatihan khusus kepada karyawan setidaknya sekali atau dua kali dalam sebulan.

Atribut bangga mengkonsumsi madu lokal memiliki kesesuain 89,07\% 
yang artinya konsumen belum merasakan kepuasan terhadap produk ini. Atribut kecepatan melayani sering kali pesanan yang ditunggu relatif lama karena karyawan harus membuat nota belanja dulu dan mencatat data konsumen pada saat konsumen sedang ramai yang memerlukan waktu untuk menunggu.

Perhitungan index kepuasan konsumen pada madu Syaiful menyatakan bahwa merasa puas terhadap kinerja dari masing-masing atribut. Namun, nilai CSI belum mencapai 100\% sehingga tingkat kepuasan konsumen belum mencapai pada tingkat maksimum. Untuk meningkatkan kepuasan konsumen perlu perlu dilakukan analisis lanjutan dengan dengan menggunakan alat bantu yaitu Importance Performance Analysis (IPA), sehingga dapat menentukan atribut mana yang menjadi prioritas utama untuk diperbaiki dan prioritas rendah dalam hal perbaikan kinerja. Serta atribut yang terletak dalam pertahankan prestasi juga harus dipertahankan kinerjanya dan atribut yang berlebihan dapat digunakan untuk menutupi kekurangan yang ada pada madu Syaiful.

\section{Prioritas Perbaikan Atribut}

Diagram IPA menggambarkan kombinasi nilai tingkat kepentingan dan nilai tingkat kinerja berdasarkan penilaian responden. Hubungan keduannya akan dapat menggambarkan prioritas perbaikan dari setiap atribut berdasarkan kuadrat masing-masing. Dalam perhitungan analisis IPA dapat menggunakan Software SPSS Statistic 21. Berdasarkan hasil penilaian 100 responden, diperoleh nilai rata-rata dari tingkat kepentingan dan tingkat kinerja setelah konsumen mendapatkan produk dan pelayanan dari madu Syaiful. Selanjutnya, dari hasil perhitungan nilai rata-rata tersebut digambarkan ke dalam diagram kartesius. Untuk membagi kuadran menjadi empat bagian digunakan nilai rata-rata index tingkat kepentingan sebesar 3,80 dan nilai rata-rata indeks tingkat kinerja sebesar 3,55 posisi masing-masing atribut tersebut dapat dilihat pada diagram kartesius. 


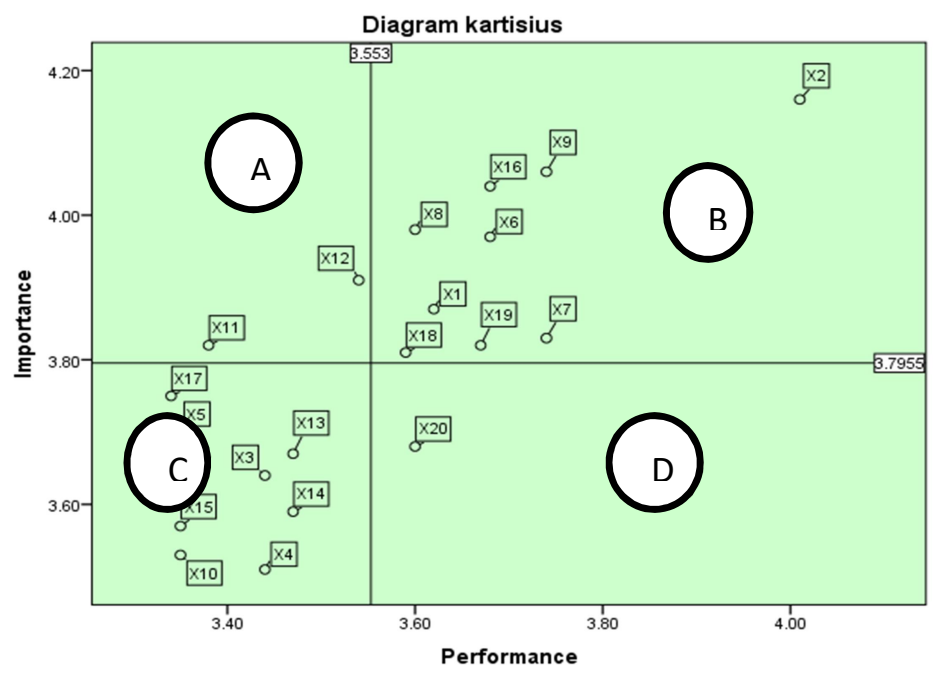

Gambar 1.diagram kartesius tingkat kepentingan dan tingkat kinerja

Keterangan:

A kuadran A

B kuadran B

C kuadran C

D kuadran D

$\mathrm{X} 1$ cita rasa madu

X2 manfaat madu

X3 warna madu

X4 aroma madu

X5 variasi madu

X6 kemasan madu

X7 kehigienisan madu

X8 kebersihan ruangan
X9 keramahan dan kesopanan karyawan

$\mathrm{X} 10$ karyawan berpenampilan rapi

X11 pengetahuan karyawan tentang madu

X12 kecepatan melayani

X13 kecepatan merespon keluhan konsumen

X14 harga terjangkau

X15 harga sesuai kualitas madu

X16 potongan harga

X17 bangga mengkonsumsi madu lokal

X18 bangga membeli madu bermerek

X19 lokasi mudah dijangkau

X20 harga murah

\section{Kuadran A (prioritas utama)}

Kuadran A adalah wilayah yang memuat atribut-atribut yang dianggap penting oleh konsumen, tetapi pada kenyataannya atribut-atribut tersebut belum sesuai dengan yang diharapkan (tingkat kepuasan yang diperoleh masih rendah). Atribut-atribut yang masuk dalam kuadran ini harus lebih ditingkatkan lagi dengan cara melakukan perbaikan terus-menerus sehingga tingkat kepuasan dari atribut yang ada di kuadran ini meningkat (Rangkuti, 2010).
Pengetahuan karyawan tentang madu berperang penting dalam pelayanan karena pengetahuan karyawan dibutuhkan untuk menjelaskan produk madu yang dijual agar konsumen merasa lebih yakin terhadap produk madu yang dijual. Pentingnya pengetahuan karyawan tentang madu bukan hanya menjelaskan produk madu, tetapi mampu menjelaskan secara detail tentang kualitas produknya seperti apa, dari bahan yang seperti apa, cara mengkonsumsinya bagaimana dan manfaat atau fungsinya untuk apa. Hasil 
penelitian (Agung, 2013) menyatakan pengetahuan karyawan madu tentang madu belum maksimal, konsumen mendapatkan pengetahuan tentang madu bukan dari karyawan melainkan dari keterangan yang sudah tertera di label botol madu yang dijual. Salah satu cara yang dilakukan madu untuk memperbaiki kinerja yaitu aktif dalam menjelaskan produk madu pada konsumen. Pengetahuan karyawan tentang madu berpengaruh terhadap keputusan pembelian madu.

kecepatan melayani yang dilakukan karyawan madu Syaiful saat ini untuk melayani satu konsumen membutuhkan waktu 5 menit. Pada saat konsumen ramai kecepatan melayani membutuhkan waktu hingga 10 menit. menurut konsumen pesanan yang dibeli sering kali relatif lama saat konsumen sedang ramai yang memerlukan waktu hingga 5 menit untuk menunggu. Salah satu cara yang dapat dilakukan pihak madu Syaiful untuk memperbaiki kinerjanya dengan menambah karyawan pada kondisi ramai pengunjung agar konsumen tidak bosan karena menunggu lama. Hasil penelitian (Heryana, 2008) menyatakan kecepatan melayani belum maksimal karena konsumen kadang harus menunggu pembuatan nota atau catatan data konsumen yang membuat konsumen menunggu sedikit lama. Salah satu cara yang dapat dilakukan oleh madu Syaiful untuk memperbaiki kinerjanya adalah mencatat atau membuat nota khusus konsumen yang membutuhkan nota, karena tidak semua konsumen tidak membutuhkan nota. Kecepatan melayani berpengaruhi terhadap keputusan pembelian.

\section{Kuadran B (Pertahankan Prestasi)}

Kuadran B adalah wilayah yang memuat atribut yang dianggap penting oleh konsumen dan atribut yang dianggap konsumen sudah sesuai dengan yang dirasakannya sehingga tingkat kepuasannya relatif lebih tinggi. Atribut yang termasuk dalam kuadran ini harus tetap dipertahankan karena semua atribut tersebut menjadikan unggul di mata konsumen (Rangkuti, 2010).

Cita rasa yang diberikan madu Syaiful memiliki rasa yang manis, tidak terlalu asam dan pahit karena madu yang dijual adalah madu Syaiful standar lokal, madu Syaiful mangarove, dan madu Syaiful kelulut, konsumen menilai cita rasa madu yang dijual sudah sesuai yang diinginkan konsumen yaitu rasa yang manis, tidak terlalu asam, pahit dan memiliki kekentalan yang pas. Hasil penelitian yang dilakukan (Heryana, 
2008) menyatakan babwa rasa madu merupakan faktor yang sangat penting bagi konsumen dalam keputusan untuk pembelian berikutnya.

Manfaat madu yang dirasakan konsumen sangat baik karena setelah mengkonsumsi madu Syaiful konsumen merasa stamina tubuh atau ketahanan tubuh meningkat, penyakit yang dirasakan seperti maag, batuk, darah tinggi dan lainya jauh lebih baik dari sebelumnya. Dari hasil penelitian dilapangan sebagian besar konsumen madu Syaiful merasa puas karena menilai manfaat madu yang mereka rasakan seperti stamina tubuh lebih kuat, ketahanan tubuh meningkat, dan untuk pengobatan penyakit tertentu sesuai yang diharapkan Hasil penelitian (Putriwindani, 2011) menyatakan bahwa atribut manfaat memiliki tingkat kepentingan yang tinggi dengan kinerja yang baik di mata konsumen sehingga perusahaan perlu mempertahankan kualitas madu agar kinerja dari manfaat madu tetap baik .

Kemasan yang digunakan terbuat dari bahan plastik khusus minuman yang aman, higienis, dan tutupan botol madu sangat kuat sehingga terhindar dari semut, lalat, debu dan sampah lainnya. Konsumen menilai kemasan yang digunakan sangat unik karena pada botol kemasan tertera jelas nama atau merek madu Syaiful dengan dekorasi gambaran menarik seperti gambar lebah, madu, dan hutan yang dapat membuat kemasan madu Syaiful terlihat lebih indah dan menarik. Hasil penelitian (Putriwindani, 2011) menyatakan bahwa apabila perusahaan ingin meningkatkan kinerja atribut kemasan, maka perusahaan perlu mempertimbangkan kembali rencananya. Salah satu alternatif yang dapat dilakukan oleh perusahaan untuk meningkatkan kinerja atribut kemasan yaitu dengan mendesain kemasan yang lebih menarik dengan bahan yang dapat memudahkan konsumen dalam proses konsumsi, misalnya menggunakan bahan dari plastik (bukan gelas). Hal ini dapat dilakukan jika perusahaan memiliki sumberdaya yang memadai.

Kehigienisan madu yang diberikan madu Syaiful yaitu bersih tidak terdapat kotoran baik dari dari, debu dan kotoran lebah karena sebelum dikemas madu disaring. Botol yang digunakan untuk mengemas madu dari bahan yang aman dan khusus minuman serta memiliki tutupan yang kuat sehingga madu yang dijual terhindar dari debu, semut, nyamuk, dan bahan kotoran yang lainnya. Konsumen merasa puas dengan kinerja 
kehigienisan madu karena madu yang mereka konsumsi maupun perlengkapan yang digunakan sudah higienis, dalam atrian tidak terdapat kotoran atau bahan berbahaya dikeduanya.

Kebersihan dan kerapian sarana prasarana juga merupakan hal penting selalu dijaga oleh toko Syaiful. Para karyawan toko Syaiful selalu melakukan bersih-bersih (menyapu, mengepel, dan lap lemari kaca, dan lain- lain) sebanyak dua kali sehari, yaitu saat buka di pagi hari dan tutup toko di malam harinya, dan juga menata madu dengan rapi dan teratur di dalam lemari kaca agar terlihat lebih mudah saat konsumen ingin membeli. Hasil penelitian (Heryana, 2008) menyatakan bahwa ruangan yang bersih akan menimbulkan suasana indah, sehingga membuat konsumen merasa betah ketika berkunjung ke outlet madu. Selain itu, kebersihan ruangan akan meningkatkan hasrat untuk berkunjung kembali.

Keramahan dan kesopanan karyawan termasuk peranan penting dalam melayani konsumen, para karyawan madu Syaiful harus selalu ramah dan sopan dalam melayani, seperti saat ada konsumen yang berkunjung ke toko untuk membeli madu, karyawan mempersilakan masuk ke toko dengan wajah yang tersenyum dan mempersilakan untuk duduk, dan menanyakan madu apa yang ingin dibeli konsumen, serta ajak konsumen untuk berbicara. Konsumen merasa puas dengan keramahan dan kesopanan karyawan toko Syaiful karena melayani konsumen dengan baik, selalu tersenyum saat melayani konsumen dan terlihat tidak kaku sehingga konsumen yang datang akan merasa lebih betah, nyaman dan senang. Menurut penelitian (Putriwindani, 2011), pelayanan sangat penting karena pelayanan karyawan yang selalu ramah dan sopan dalam melayani konsumen membuat konsumen merasa lebih senang dan nyaman saat berkunjung untuk membeli produk.

Potongan harga yang ditawarkan oleh toko madu Syaiful bervariasi, yaitu jika membeli madu Syaiful merek apa saja dengan harga lebih dari Rp 300.000 maka akan mendapatkan potongan harga Rp 15.000, untuk pembelian dengan harga lebih dari Rp 500.000 maka akan mendapatkan potongan harga $\mathrm{Rp}$ 100.000, dan untuk pembelian yang lebih dari Rp 600.000 maka akan mendapatkan potongan harga sebesar Rp 120.000. Konsumen menilai potongan harga yang diberikan sudah terjangkau sesuai dengan kualitas produk yang dijual sehingga 
konsumen merasa puas terhadap potongan harga yang diberikan. Menurut (Kotler, Philip, \& Keller, 2016), potongan harga merupakan penghematan yang ditawarkan pada konsumen dari harga normal suatu produk yang tertera di kemasan produk tersebut.

Bangga mengkonsumsi produk lokal bermerek. Bangga merupakan perasan yang dirasakan seseorang saat memiliki apa diinginkan, bangga membeli produk lokal bermerek merupakan suatu faktor penting yang mendorong konsumen untuk melakukan pembelian madu Syaiful karena madu Syaiful mempunyai kelebihan atau keunggulan tersendiri dibandingkan merek madu lokal lainnya yang ada di kota Pontianak. Produk yang ditawarkan toko Syaiful mempunyai banyak peminat serta mempunyai kualitas produk yang tidak kalah saing dibandingkan produk bermerek yang sudah terkenal di seluruh Indonesia. Menurut (Irawan, 2009), konsumen akan merasa bangga dan mendapatkan keyakinan bahwa orang lain akan kagum terhadap dia bila menggunakan atau mengkonsumsi dengan merek tertentu yang cendrung mempunyai tingkat kepuasan yang lebih tinggi. Kepuasan yang diperoleh bukan karena kualitas dari produk tetapi nilai social yang membuat konsumen menjadi puas terhadap merek tertentu

Lokasi toko Syaiful yang berada di jalan raya dan banyaknya jalan anternatif memberikan kemudahan bagi konsumen untuk mengunjungi toko Syaiful. Konsumen madu Syaiful menilai bahwa akses lokasi toko Syaiful letaknya strategi dan mudah dijangkau. Konsumen tidak kesulitan dalam mencari toko Syaiful karena berada tepat di pinggir jalan yang merupakan akses jalan umum yang membuatnya mudah ditemukan dan mengingat atau menghafal lokasinya. Menurut (Cristina, 2010), lokasi penjualan dapat mempengaruhi jumlah dan jenis konsumen yang akan tertarik utuk datang ke lokasi yang strategi, mudah dijangkau oleh sarana transportasi yang ada, serta lokasi yang mudah diakses.

\section{Kuadran C}

Kuadran $\mathrm{C}$ adalah wilayah yang memuat atribut yang dianggap penting oleh konsumen madu dan kenyataannya tingkat kepuasannya tidak terlalu istimewa. Atribut yang termasuk dalam kuadran ini adalah:

Warna madu merupakan faktor alami yang tidak bisa dirubah oleh penjual karena jika dirubah sesuai keinginan konsumen bisa jadi keaslian 
madu bisa berkurang atau hilang, Atribut warna madu merupakan satu atribut yang tidak dapat didesain atau dibuat oleh madu Syaiful sehingga madu Syaiful tidak dapat menyesuaikan warna madu agar sesuai selera konsumen. Warna madu yang ditawarkan antara lain warna gelap untuk jenis madu Syaiful Kelulut, warna kecoklatan untuk jenis madu Syaiful standar lokal dan warna sedikit terang untuk jenis madu Syaiful mangrove. Konsumen menilai warna madu yang dijual cukup sesuai dengan yang diharap. Hasil penelitian (Putriwindani, 2011) menyatakan bahwa konsumen menilai kinerja dari atribut warna madu belum sesuai yang diharapkan, konsumen menilai warna madu belum stabil padahal yang sebenarnya warna madu tergantung dari netral bunga yang jadi tempat saran lebah, karena setiap saran lebah yang berbeda netral bunga bisa menhasilkan warna madu yang berbeda pula

Aroma madu merupakan salah satu ciri khas yang dimiliki madu, aroma madu ada yang lembut ada yang menyengat sesuai netral bunga. Sebelum madu dikemas pertama kali tercium adalah wangi bunga yang menjadi bahan netral, misalnya mangrove, kelengkeng, akasia, dan lainnya. Demikian saat sudah dikemas aroma masih masih tercium sesuai netral bunga yang dihasilkan. Konsumen merasa cukup puas dengan aroma madu Syaiful, namun perlu ditingkatkan lagi akan konsumen merasa jauh lebih puas. (Putriwindani, 2011) menyatakan bahwa atribut aroma madu tidak memiliki tingkat kepentingan yang tinggi bagi konsumen sehingga tidak menjadi salah satu atribut yang diperhitungkan dalam proses pembelian madu

Variasi madu. Konsumen menilai variasi madu yang diberi sudah baik namun masih belum sesuai yang diharapkan konsumen karena ukurannya belum terlalu lengkap, oleh karena itu pihak madu Syaiful perlu mengevaluasi lagi ukuran apa yang diinginkan konsumen agar konsumen merasa lebih puas. Hasil penelitian (Agung, 2013) menyatakan variasi madu yang dijual sudah baik, namun pihak penjual harus terus memantau agar semua ukuran madu yang diinginkan konsumen dapat terpenuhi.

\section{Karyawan berpenampilan rapi.}

Menurut konsumen, penampilan sudah rapi namum tidak ada yang berbeda dengan karyawan madu madu lainnya, kesannya biasa saja tidak terdapat perbedaan tempat lain, sehingga 
konsumen merasa perlu ditingkatkan agar konsumen lebih puas terhadap kinerja dari atribut karyawan berpenampilan rapi. Hasil penelitian (Heryana, 2008) menyatakan sudah sangat baik konsumen menilai bahwa karyawan menggunakan pakaian bersih dan rapi. Selain itu, karyawan juga tidak berlebihan dalam berdandan. Oleh karena itu, atribut ini harus dipertahankan.

\section{Cepat merespon keluhan}

konsumen. Konsumen menilai kinerja dari atribut cepat merespon keluhan konsumen sudah baik, namun belum dengan keinginan konsumen sehingga tingkat kinerjanya perlu ditingkatkan lagi karena atribut cepat merespon keluhan konsumen menjadi bahan pertimbangan untuk keputusan pembelian selanjutnya. Hasil penelitian (Putriwindani, 2011) menyatakan bahwa kecepatan karyawan dalam menanggapi keluhan konsumen dinilai konsumen sudah baik. Karyawan cepat tanggap terhadap segala keluhan yang disampaikan oleh konsumen. Konsumen akan merasa senang bila segala keinginannya terpenuhi. Maka dari itu, pihak perusahaan harus mempertahankan atribut ini, agar kepuasan konsumen selalu terpenuhi dan kepercayaan konsumen yang diberikan selalu terjaga.
Harga yang ditawarkan oleh toko Syaiful sedikit jauh lebih mahal dibandingkan dengan merek madu lokal yang lain, harga yang ditawarkan tergantung merek madu dan ukuran madu. pada umunya harga yang ditawarkan toko Syaiful untuk madu ukuran 250 ml Rp 55.000, untuk ukuran 500 gram dengan jual $\mathrm{Rp} 135.000$, dan untuk ukuran $1.000 \mathrm{ml}$ Rp 270.000 . menurut penilai konsumen harga madu yang ditawarkan cukup tinggi sehingga kadang ada konsumen yang membatalkan niat untuk membeli karena belum cukup uang untuk membeli. Hasil penelitian (Suherman, Kadarsih, \& Gusmantaro, 2017) menyatakan konsumen menginginkan informasi dan konsistensi harga madu di pasaran, sehingga konsumen dapat menentukan pilihan produknya dengan tepat sesuai yang mereka butuhkan.

Harga sesuai kualitas madu, harga yang ditawarkan cukup tinggi dibandingkan harga madu yang lain namun kualitas madunya sama dengan madu lokal merek lainnya. Konsumen madu Syaiful merasa belum puas dengan atribut harga sesuai kualitas madu untuk itu madu Syaiful perlu melakukan evaluasi terkait kualitas madu dan harga yang ditawarkan. Konsumen menilai 
atribut dari harga sesuai kualitas madu sudah cukup baik namun perlu meningkatkan kualitas dan mempertimbangkan lagi harga agar dapat membuat konsumen merasa lebih puas. Hasil penelitian (Selmi, Putri, \& Rustama, 2017) menyatakan konsumen akan memilih produk yang memiliki kualitas baik, mengingat belum adanya jaminan dan kualitas madu yang banyak terjual di pasaran, sehingga membuat masyarakat menjadi ragu dan kurang percaya untuk membeli madu.

Bangga mengkonsumsi produk local. Konsumen menilai tingkat kinerja dari atribut dari bangga mengkonsumsi produk lokal sudah baik nanum perlu ditingkatkan lagi karena menurut konsumen walaupun bangga mengkonsumsi produk lokal bermerek namun belum memiliki perbedaan yang menonjol dibandingkan produk lain. Untuk meningkatkan kinerja dari atribut bangga mengkonsumsi madu lokal bermerek, madu Syaiful perlu melakukan pertimbangan serta menciptakan sesuatu yang dianggap mempunyai nilai tamah atau plus dibandingkan produk madu lainnya. Menurut (Irawan, 2009), rasa bangga merupakan bagian dari emotional factor. Bangga terhadap apa yang dibeli atau digunakan merupakan suatu kepuasan tersendiri bagi konsumen yang dapat mempengaruhi kepuasan konsumen.

\section{Kuadran D}

Kuadran D adalah wilayah yang memuat atribut yang dianggap penting oleh konsumen, akan tetapi pelaksanaannya dilakukan dengan baik sekali oleh pihak toko Syaiful sehingga pelaksanaannya dirasakan terlalu berlebihan. Madu Syaiful memiliki produk yang memiliki banyak stok sehingga konsumen tidak pernah kesusahan saat ingin membeli konsumen, namum pada kenyataan konsumen merasa produk yang disediakan lebih dari yang dibutuhkan sehingga sebaiknya dilakukan penyedia sesuai permintaan agar tidak terlalu menghabiskan banyak biaya dan hemat. Konsumen madu Syaiful menilai madu yang disediakan sangat baik bahkan berlebihan oleh karena itu perlu adanya pengurangan agar lebih hemat. Menurut hasil penelitian dari (Palma \& Andjarwati, 2016), kemudahan pelanggan dalam memperoleh suatu produk meningkat maka niat beli ulang akan meningkat pula. Hasil penelitian yang dilakukan juga (Hardiawan, 2013) menyatakan bahwa kemudahan berpengaruh positif terhadap kepuasan, 
sehingga konsumen akan melakukan pembelian kembali.

\section{KESIMPULAN DAN SARAN}

Berdasarkan hasil analisis tingkat kinerja dan tingkat kepentingan konsumen madu Syaiful, maka disimpulkan "PUAS" namun perlu adanya perbaikan terhadap atribut yang dianggap tingkat kinerjanya masih kurang atau belum sesuai dengan harapan konsumen. Prioritas atribut kinerja yang harus ditingkatkan adalah warna madu, variasi madu, aroma madu, karyawan berpenampilan rapi, cepat merespon keluhan konsumen, harga terjangkau, harga sesuai kualitas madu, dan bangga mengkonsumsi produk lokal. Atributartibut perlu ditingkatkan agar jauh lebih baik dari sebelumnya.

Berdasarkan penelitian yang dilakukan maka saran yang diberikan adalah atribut warna madu, aroma madu, variasi madu, karyawan berpenampilan rapi, cepat merespon keluhan konsumen, harga terjangkau, harga sesuai kualitas madu dan atribut bangga mengkonsumsi madu lokal perlu diperbaiki dan meningkatkan kinerjanya dengan cara mempertimbangan keluhan atau pendapat dari konsumen agar menciptakan kepuasan sesuai yang diinginkan konsumen.

\section{DAFTAR PUSTAKA}

Agung, N. (2013). Analisis Kepuasan Pelanggan Produk Madu Super Yang Dipentingkan Studi Kasus C.V Mutiara Tugu Ibu. Bogor: IPB (Bogor Agricultural University).

Cristina, W. U. (2010). Manajemen Ritel_Strategi Dan Implementasi Operasional Bisnis Ritel Modern Di Indonesia. Jakarta: Salemba Empat.

Hardiawan, A.C. (2013). Pengaruh Kepercayaan, Kemudahan, Dan Kualitas Informasi Terhadap Keputusan Pembelian Secara Online. Fakultas Ekonomi Dan Bisnis Universitas Diponogero.

Heryana. (2008). Analisis Kepuasan Konsumen Madu Mutiara Tugu Ibu. Bogor: IPB (Bogor Agricultura University).

Irawan. (2009). Sepuluh Prinsip Kepuasan Konsumen Pelanggan. Jakarta: Elex Media Komputido.

Kotler, Philip, \& Amstrong. (2012). Prinsip-Prinsip Pemasaran Edisi 13. Jakarta: Erlangga.

Kotler, Philip, \& Keller. (2016). Marketing Managemen. Jakarta: Pearson Educatin, Inc.

Nur, U. (2014). Kepuasan Konsumen Dan Analisis Sensitivitas Harga Produk Madu Pramuka Di PT. Madu Pramuka. Bogor: IPB (Bogor Agricultural University).

Palma, M. A., \& Andjarwati, A. L. (2016). Pengaruh Kualitas Produk, kemudahan, dan harga terhadap niat beli Ulang Dengan Kepuasan Sebagai Variabel Intervening. Jurnal Riset Ekonomi Dan Manajemen, 1(16), 84-104. 
Putriwindani, R.M. (2011). Analisis Proses Keputusan Pembelian Dan Kepuasan Konsumen Madu Pramuka PT. Madu Pramuka Serta Implikasinya Terhadap Bauran Pemasran. Bogor: IPB (Bogor Agricultural University).

Rangkuti. (2010). Teknik Mengukur Dan Strategi meningkatkan Kepuasan Pelanggan Plus Analisis Kasus PLN-JP. Jakarta: Gramedia Pustaka Utama.
Selmi, Putri, Dan Rustama. (2017). Perilaku Dan Loyalitas Konsumen Madu. Jurnal AGRISEP, 1(16), 1324.

Suherman, Kadarsih, Dan Gusmantaro. (2017). Strategi Pemasaran Madu Berdasarkan Karakteristik Konsumen. Jurnal Sains Peternakan Indonesia, 2(12), 171172. 